\title{
Bibliotherapy to Improve Self-control in the Prevention of Sexual
} Harassment

\author{
Berliantika Putri Azwir, Firman Firman, Herman Nirwana dan Syahniar \\ Email : firman@konselor.org
}

\begin{abstract}
Individuals who have low self-control tend to behave in a distorted way, including behaviors that lead to sexual harassment. Therefore, appropriate service implementation guidelines are needed to improve student self-control in preventing sexual harassment. This study aims to reveal the feasibility and dependability of service implementation guidelines. The method used in this research is $\mathrm{R} \& \mathrm{D}$ with development of ADDIE model. The trial subjects consisted of six experts to check the eligibility of the guidelines and three counselors for the dress code. This research is done through testing FGD product. Data analysis used is descriptive and inferential analysis. The results show that the service implementation guidelines are considered feasible and the level of dependability in the category is very high.
\end{abstract}

Keywords: Bibliotherapy, Self-control and Sexual Harassment.

This is an open access article distributed under the Creative Commons 4.0 Attribution License, which permits unrestricted use, distribution, and reproduction in any medium, provided the original work is properly cited. C2018 by author and Faculty of education, Universitas Negeri Padang.

\section{Introduction}

Individuals with low self-control are unable to regulate and direct their behavior, so it is assumed that a student with low self-control tends to behave and act more on things that are pleasing to him including by channeling his sexual desires in the form of dating or prostitution. Furthermore, research results (Angelina \& Matulessy, 2013; Arief, 2017; Artaria, 2002; Serpianing, Dewi, \& Suminar, n.d.; Syarifah Fauzi'ah, 2016) that adolescents with low self-control tend to engage in sexual behavior.

The higher the ability of one's self-control will be more able to prevent the sexual behavior (Joseph, 2015; Kaygusuz \& Ozpolat, 2016; Mulkan, 2016; Pitoyo, 2016; Supanto, 2004). This is due to the lack of adolescents' ability to control and control themselves, especially the emotions, which often make teenagers do negative things such as sexual harassment without thinking about the impact and risks it creates (Herdiana, 2012; Immanuel, 2016; Jatmika, 2012).

Therefore, adolescents need self-control because adolescents do not have adequate experience. Rapid physical and sexual growth causes shock and indecision in adolescence, especially 
when adolescents begin to engage in intercourse with the opposite sex, leading to sexual cases (Alsmadi \& Bani-abduh, 2017; Puspita, Erlamsyah, \& Syahniar, 2013; Wulaningsih \& Hartini, 2015). Information is used as a reference to behave and behave daily, as a consideration for the direction of self-development and as a basis for decision making (Prayitno, 2012)

Based on the explanation, the Counselor Teachers / Counselors at the school made the issue a problem in the aid effort to the students because they have not found the right guidance in improving students' self-control in Vocational High School (SMK). Therefore, it is interesting to explore further through the research of how the information service guide to improving self-control in the prevention of adolescent sexual abuse tendency.

\section{Method}

The method used in this research is Research \& Development with the development of ADDIE (Analyze, Design, Development, Implementation, and Evaluation) model. The trial subjects consisted of six experts to check the eligibility of the guidelines and three counselors for the dress code. This research is done through testing FGD product. Data analysis used is descriptive and inferential analysis.

\section{Results and Discussion}

Based on the results of feasibility tests by experts, obtained data as follows:

Table 1. Data of Results Expert Validation Bibliotherapy Material

\begin{tabular}{ll}
\hline Aspects & $\%$ \\
\hline Term of reference & 78 \\
\hline General instructions of bibliotherapy & 72 \\
\hline Contents of bibliotherapy & 74 \\
\hline Topics presented & 80 \\
\hline Use of language & 80 \\
\hline Plan of bibliotherapy & 80 \\
\hline Total & 76.96 \\
\hline
\end{tabular}


Table 2. Data of Results Expert on Bibliotherapy Views

\begin{tabular}{ll}
\hline Aspects & $\%$ \\
\hline Cover design & 85 \\
\hline Type and size of letters on material & 90 \\
\hline The colors used & 91 \\
\hline Punctuation used & 87 \\
\hline Imaged used & 71 \\
\hline Space or blank space & 90 \\
\hline Consistency & 91 \\
\hline Quality of bibliotherapy & 87 \\
\hline Total & 86.66 \\
\hline
\end{tabular}

Overall, the developed bibliotherapy is categorized as material-worthy of guidance and highly feasible in guidance view. The alignment of the assessment is obtained from the probability score of the guidance expert, which is 0,000 and the pre will score of the expert viewing guide, which is 0.000 . The score is below the level of significance, which is 0.05 .

At the analytical stage, the required materials are needed to improve self-control in preventing sexual harassment, namely sexual harassment, self-control, tips on improving cognitive control in preventing student sexual abuse, tips on improving behavioral controls in preventing student sexual abuse and tips on improving decision-making controls in preventing student sexual abuse. At the development stage, it is found that the guidelines are in the category of material worth and are highly feasible in appearance. Then, there is an alignment of an objective assessment of the resulting product. 
Assessment of bibliotherapy applied by BK teachers/counselors in schools as in Table 3 below:

Table 3. Data of Results of Dressing

\begin{tabular}{lc}
\hline Aspects & \% \\
\hline Planning & 88 \\
\hline Implementation & 92 \\
\hline Evaluation & 95 \\
\hline Total & $\mathbf{9 2}$ \\
\hline
\end{tabular}

Assessment from the counselor states that bibliotherapy is in a very high category. The alignment of judgments is obtained from a probability score of 0,000 . The score is below the level of significance, which is 0.05 . That is, there is an alignment assessment between the counselor of the assessed product.

Implementation of bibliotherapy to improve self-control in the prevention of students' sexual harassment has been achieved to a sufficient degree of adequacy. All aspects of planning can be done by the counselor well. The counselor can provide all the necessary tools, can follow the steps that have been prepared, and the counselor is able to see the progress of students after following the service. The use of this guide leads students to increase self-control in order to prevent themselves from sexual harassment. Service activities focused on students and counselors only as facilitators. Thus, the counselor may use the guide in practice.

Based on the implementation of FGD to the three counselors, it can be concluded that the overall bibliotherapy developed has received a very good appreciation and is expected to be implemented in the learning process.

\section{Conclusions}

Based on the results of research and discussion, it can be concluded that :

1. Bibliotherapy to improve self-control in the prevention of sexual harassment lies in a category that is materially feasible and highly feasible in appearance. This means experts say that bibliotherapy can be implemented for students. 
2. The level of exposure is in a very high category. That is, bibliotherapy can be used as a medium in the implementation of school counseling services.

In this case, counselors are expected to play an active role in improving student self-control in order to prevent sexual harassment. Counselors can develop service programs as needed.

\section{References}

Al-smadi, M. S., \& Bani-abduh, Y. M. (2017). Standardization of the Self Control and Self-management Skills Scale SCMS on the Student of University of Najran, 5(3), 453-460.

https://doi.org/10.13189/ujer.2017.050317

Angelina, D. Y., \& Matulessy, A. (2013). Pola Asuh Otoriter , Kontrol Diri. Jurnal Psikologi Indonesia, 2(2), 173-182.

Arief, H. (2017). Rekonstruksi Hukum tentang Hukuman kebiri bagi Pelaku Tindak Pidana Pelecehan Seksual. Jurnal Khazanah, 14(1), 110-132.

Artaria, M. D. (2002). Efek Pelecehan Seksual di Lingkungan Kampus: Studi Preliminer, 1/No.1, 53-72. Herdiana, I. (2012). Dampak Psikososial Pada Anak Jalanan Korban Pelecehan Seksual Yang Tinggal di Liponsos Anak Surabaya. Jurnal Psikologi Kepribadian Dan Sosial, 1(2), 68-73.

Immanuel, R. D. (2016). MENGALAMI PELECEHAN SEKSUAL. PSIKOBORNEO, 4(2), 312-320.

Jatmika, D. (2012). Straegi Coping Perempuan Korban Plecehan Seksual Ditinjau Dari Tipe Kepribadian “ EYSENCK.” Jurnal Psikologi Ulayat, 2(1), 107-118.

Joseph, J. (2015). Sexual Harassment in Tertiary Institutions: A Comparative Perspective. Temida, 1450-6637, 125-144. https://doi.org/10.2298/TEM1502125H

Kaygusuz, C., \& Ozpolat, A. R. (2016). An Analysis of University Students' Levels of Self-control According to Their Ego States. Eurasian Journal of Educational Research. https://doi.org/10.14689/ejer.2016.64.11

Mulkan, K. (2016). The Relationship Between Self Control And Self Esteem With Students' Moral Intelligence in SMK Sinar Husni TR Labuhan Deli. Analitika, 8(2), 89-98.

Pitoyo, A. J. (2016). Combatting Sexual Harassment Against Women Migrant Workers Overseas: Looking at the Contextual Factors. Psychology Social, 24(1), 36-56.

Prayitno. (2012). Jenis Layanan dan Kegiatan Pendukung Konseling. Padang: FIP UNP.

Puspita, M., Erlamsyah, \& Syahniar. (2013). Hubungan antar Perlakuan Orangtua dengan Kontrol Diri Siswa di Sekolah. Jurnal Ilmiah Konselor, 1(1), 330-337.

Serpianing, I., Dewi, A., \& Suminar, R. (n.d.). Hubungan Antara Tingkat Kontrol Diri Dengan Kecenderungan Perilaku Kenakalan Remaja.

Supanto. (2004). Pelecehan Seksual sebagai Kekerasan Gender: Antisipasi Hukum Pidana. Jurnal 
Hukum Pidana, XX(3), 288-310.

Syarifah Fauzi'ah. (2016). Faktor Penyebab Pelecehan Seksual terhadap Anak, IX, 81-101.

Wulaningsih, R., \& Hartini, N. (2015). Hubungan antara Persepsi Pola Asuh Orangtua dan Kontrol Diri Remaja terhadap Perilaku Merokok di Pondok Pesantren. Jurnal Psikologi Klinis Dan Kesehatan Mental, 4(4), 119-126. 